\title{
The Platform Switching Concept-A Myth or Fact: A Literature Review
}

\author{
${ }^{1}$ Sanjeev Mittal, ${ }^{2}$ Shivali Goyal, ${ }^{3}$ Sahil Sekhri
}

\begin{abstract}
The peri-implant bone level has been used as one of the criteria to assess the success of dental implants. It is an important prerequisite for preserving the integrity of gingival margins and interdental papillae. Platform switching for maintaining periimplant bone levels has gained popularity among implant manufacturers over the last few years. Typically, crestal bone levels are situated 1.5 to $2 \mathrm{~mm}$ below the implant-abutment junction, dependent on various factors and there are several theories stating the reason for this phenomenon. Platform switching is a concept which aims at reduction of the crestal bone loss around the implants and involves the restoration of implants with smaller diameter abutments such that the implant abutment junction (IAJ) is horizontally repositioned inwardly and away from the outer edge of the implant platform. This review aims at summarizing the significance of platform switching.
\end{abstract}

Keywords: Platform switching, Dental, Implants.

How to cite this article: Mittal S, Goyal S, Sekhri S. The Platform Switching Concept-A Myth or Fact: A Literature Review. Int J Oral Implantol Clin Res 2014;5(2):55-59.

\section{Source of support: Nil}

Conflict of interest: None

\section{INTRODUCTION}

Gap between implant and abutment leads to bacterial colonization. Chewing loads cause a relative movement between the components. This distributes endotoxins, causing an infectious reaction in the tissue at the implant-abutment interface level. Bone is resorbed below the implant-abutment connection (IAJ) until the biological width is established. Only a bacteria-proof connection prevents bone resorption and stabilizes the soft tissue.

Concept of platform switching is about increasing the width of the epithelial collar around the abutment, hence, resulting in thicker and tighter seal around the abutment minimizing the pocketing around the abutment. It empha-

${ }^{1}$ Professor, ${ }^{2,3}$ Postgraduate Student
${ }^{1-3}$ Department of Prosthodontics, Maharishi Markandeshwar
College of Dental Sciences and Research, Ambala, Haryana, India

Corresponding Author: Shivali Goyal, Postgraduate Student Department of Prosthodontics, Maharishi Markandeshwar College of Dental Sciences and Research, Ambala, Haryana India, Phone: 7206177051, e-mail: shivaligoyal16@gmail.com sizes the promotion of gingival health, increases the volume of soft tissue, preserving the crestal bone levels. Discovered by accident in the late $1980 \mathrm{~s}$, the benefits of platform switching soon became a heavy focus of implant-related research and are now considered to be a means of preventing initial peri-implant bone loss.

\section{CONCEPT}

After undergoing osseointegration, dental implants are fitted with abutments in order to allow dental restorations (e.g. crowns, dentures, etc.) to be attached. Historically, the diameter of the abutment matched the diameter of the implant platform, for example, a $4.8 \mathrm{~mm}$ wide abutment was placed on a $4.8 \mathrm{~mm}$ wide implant - this can be termed platformmatching. 1

When platform switching, a narrower abutment diameter for a given implant platform diameter is used, for example, placing a $3.8 \mathrm{~mm}$ wide abutment on a $4.8 \mathrm{~mm}$ wide implant. ${ }^{1}$

\section{HISTORY AND ORIGIN OF THE CONCEPT OF PLATFORM SWITCHING}

The introduction of wide-diameter dental implants in the late 1980 s created a situation in which mismatched standarddiameter abutments were used simply because of the lack of commercial availability of components to match the wide-diameter implants. Serendipitously, it was found that these implants exhibited less than expected initial crestal bone loss - the effect of bone remodeling at the crest of the alveolar bone into which dental implants are placed, during healing. Several early clinical reports demonstrated enhanced soft (gingiva) and hard (bone) tissue responses to these platform switched implants, leading many implant companies to incorporate platform switching into their implant systems even for narrower-body implants. ${ }^{2,3}$

\section{RATIONALE}

It has been demonstrated that bone resorption at the IAJ may be caused by an inflammatory cell infiltrate that forms a zone around the IAJ. ${ }^{4}$ Although not yet fully understood, the current theory of the benefit of platform switching is related to the physical repositioning of the IAJ away from the outer edge of the implant and the surrounding bone, thereby containing the inflammatory infiltrate within the width of the platform switch. ${ }^{3}$ 
In line with the supposed mechanism of action, it is not merely the introduction of a platform switch, but the magnitude of the implant-abutment diameter mismatch, that makes a difference. Difference in bone levels became statistically significant when the implant-abutment diameter mismatch was greater than $0.8 \mathrm{~mm}$, providing a $0.4 \mathrm{~mm}$ circumferential width of platform switch when the center of the abutment is aligned with and fixed to the center of the implant. ${ }^{5}$

\section{MECHANISM BY WHICH PLATFORM SWITCHING REDUCES CRESTAL BONE LOSS}

The mechanism by which platform switching can contribute to reduce the crestal bone loss could be due to following reasons.

1. Shifting of the inflammatory cell infiltrate inwards and away from the adjacent crestal bone.

2. Maintenance of biological width and increased distance of IAJ from the crestal bone level in the horizontal way.

3. The influence of microgap on the crestal bone is reduced.

4. The stress levels in the peri-implant bone are decreased. Factors affecting crestal bone loss include surgical trauma, crest module, biological width, microgap, occlusal overload, crest module. ${ }^{6}$

Luongo et $\mathrm{al}^{7}$ studied biopsy specimen to find out the biologic process occurring around the platform-switched implant. They found that an inflammatory connective tissue infiltrate was localized over the entire surface of the implant platform and approximately $0.35 \mathrm{~mm}$ coronal to the IAJ but did not reach the crestal bone, which may be the reason for crestal bone preservation by platform-switching. Maeda et al, ${ }^{8}$ in a 3D finite element analysis, found the biomechanical advantages of platform switching. They noted that this procedure shifts the stress concentration away from the bone-implant interface, but these forces are then increased in the abutment or the abutment screw. Schrotenboer et al ${ }^{9}$ fabricated a two-dimensional model to analyze the boneimplant interactions under masticatory forces. Results showed that reduction of abutment diameter resulted in measurable but minimal effect on von Mises stresses in the crestal region of cortical bone. However, it was concluded that further clinical trials are warranted before any firm conclusion is drawn.

Canay et $\mathrm{al}^{10}$ concluded in their study that stresses are confined to the cortical bone region around the implant neck. For the designs with greater horizontal offset, intensity of stresses are higher at the abutment part resting above the bone level. Thus, platform switching may risk the mechanical properties of abutments if horizontal set-off is increased. Though decrease in abutment diameter decreases the stresses generated around the implant, the differences are very slight. Hsu et $\mathrm{al}^{11}$ concluded in their study that bone strains were reduced by $<10 \%$ when platform switching was used compared to no platform switching. Degidi et al ${ }^{12}$ evaluated the histology and histomorphology of three morse cone connection implants in a real case report and they explained that when there is zero microgap and no micromovement, platform switching shows no resorption.

\section{Biomechanical Aspect}

The bone changes occurring at the margins adjacent to the dental implants have been the subject of many clinical and experimental studies. ${ }^{13}$ Stress is concentrated around the crestal region where 2 materials with different moduli of elasticity (bone and implant) interact. Although the etiological factors underlying bone loss have not been fully established, ${ }^{14}$ the main causal factors of crestal bone loss are occlusal overload and peri-implantitis characteristics, such as implant design, crestal bone geometry and the location within the oral cavity must be taken into consideration for the optimum support and distribution of occlusal loading forces to the bone components. ${ }^{15,16}$

Biomechanical studies of dental implants using finite elements analysis software are increasingly common. ${ }^{16-18}$

Rodríguez-Ciurana et al, ${ }^{18}$ in a two-dimensional biomechanical study involving platform switching integrated into the implant design, failed to obtain peri-implant bone force attenuation values as high as those reported in earlier studies, when comparing platform expansion with a traditional restoration model. In addition, the authors concluded that force dissipation in the platform switching restoration is slightly more favorable in an internal than in an external junction, since it improves distribution of the loads applied to the occlusal surface of the prosthesis along the axis of the implant.

Such platform switching is not advisable in mandibular implant-mucosal support prostheses, since reduction of the diameter of the junction lessens the abutment resistance in response to occlusal loading applied in the posterior area of the overdentures-fundamentally compromising the connecting abutment closest to the area where loading is applied. ${ }^{19}$

\section{MICROGAP AND THE CRESTAL BONE LEVELS}

Microgap is the term used for the microscopic space where the bottom of the abutment meets the top of the implant. This tiny area would be a great place for bacteria to grow and cause bone resorption at the connection. The microgap-crestal bone level relationship was studied radiographically by Hermann et al who demonstrated that the microgap between the implant/abutment has a direct effect on crestal bone loss, independent of surgical 
approaches. Epithelial proliferation to establish biological width could be responsible for crestal bone loss found about $2 \mathrm{~mm}$ below the microgap.

Bacteria gather around these micro spaces. This dynamic movement pumps the toxins that form in the gaps and creates a 'zone of toxicity' at the level of the microgap. Alveolar bone is then remodeled below the zone, resulting in the typical bone loss down to 'first thread'. This is one of the reasons for the bone remodeling noted at the crestal area. Any micromovement compounds the effect of bone loss. The goal of platform switching is to prevent the normal bone loss down to the first thread that occurs around most implants, thus enhancing soft tissue esthetics and stability.

\section{Platform Switching to preserve the Crestal Bone}

Crestal bone loss around dental implants has been frequently documented in recent years. However, the factors implicated in the bone reabsorption and appositioning mechanisms in implant treatment are not fully clear. ${ }^{20}$

The widely accepted factors that attempt to explain the changes in bone height that occur after functional and esthetic implant-supported restoration include the gingival biotype, the distance of the IAJ from the bone crest, repositioning of the gingival inflammatory infiltrate, and the distribution of forces in the portion of the implant in contact with the cortical bone. ${ }^{17,21}$ Additional factors are loss secondary to aggression such as mucoperiosteal flap raising, second-stage surgery for exposing the screw, and colonization by bacteria belonging to the oral flora at the coronal bone and implant junction. ${ }^{20,22}$ Bone loss in twostage implant-supported restorations is estimated to be 1.5 to $2 \mathrm{~mm}$ below the IAJ, exposing one or two threads after 1 year supporting a prosthetic restoration. ${ }^{23}$

Despite these findings in the literature, some investigators consider platform expansion to be of key importance for crestal bone stability. Experimental histomorphometric studies have shown improvement in crestal bone levels in abutments with platform reduction, though statistical significance was not reached. ${ }^{21-25}$

Platform reduction with immediate functional loading in the rehabilitation of edentulous arches has also been documented in the literature. The authors consider this design of the abutment-implant complex to be decisive for crestal bone stability in both nonsmokers and smokers of more than two packs of cigarettes a day. ${ }^{26-29}$

There have also been reports of immediate postextraction rehabilitation with very satisfactory results in terms of soft and hard tissue preservation. Platform expansion in postextraction situations makes it possible to minimize the gap between the recently extracted tooth bed and the implant, acting as a physical barrier against the penetration of bacteria in the zone of contact between the bone and implant. This increase in diameter favors improved primary stability. ${ }^{11,30-34}$

\section{The Response of Soft-tissue to Platform Switching}

The most widely studied theory proposed to explain maxillary bone remodeling after dental implant placement has been the formation of a new biological space. The creation of this mechanical barrier serves as a defense mechanism, preventing the penetration of bacteria from the oral environment. ${ }^{1}$

Such physiological sealing shows morphological differences according to whether it is formed in relation to a tooth or a dental implant. The biological space adjacent to an implant is greater than the space adjacent to a natural tooth, with histological differences in terms of the organization and distribution of the fibers. In addition to differences attributable to location, the biological space of an epicrestal implant forms at subcrestal level, while in the case of a natural tooth the space is formed at supracrestal level. ${ }^{12}$

These differences in formation and morphology could be related to the corresponding vascular supply. In effect, while the soft tissues surrounding an implant are only vascularized by vessels from the periosteum, the tissues adjacent to natural teeth are also vascularized through the periodontal ligament. ${ }^{35}$

A minimum distance of $3 \mathrm{~mm}$ between implants allows sufficient margin to restore the biological space of both restorations, as demonstrated by Tarnow et al a decade ago. In implants involving an expanded platform integrated in their macrostructure, and ensuring the above mentioned distance between implants, bone crest preservation is seen to be $57 \%$ greater than with a traditional restoration design. ${ }^{33,36,37}$

According to Lazzara and Porter, the deliberate creation of a space for the mentioned physiological barrier minimizes the space for repositioning of the fibers. By displacing the junction with the abutment to a more medial position with respect to the axis, an increased surface area of the implant is freed-thus favoring controlled repositioning of the biological space. $^{38}$

The space is created in the horizontal plane one millimeter from the IAJ, supported over the external margin of the platform. In addition, this procedure keeps the inflammatory infiltrate away from the crestal bone margin, with a 50\% reduction in occupation surface. ${ }^{3,39}$ Trammell et al, ${ }^{40}$ in a case-control study, measured the biological space with reduced and conventional platform abutments in the same individual. Although the mean biological width was similar in both groups $(1.57 \pm 0.72 \mathrm{~mm}$ with the expanded platform and $1.53 \pm 0.78 \mathrm{~mm}$ with conventional abutments), bone 
loss was significantly smaller with the expanded platform. The use of Morse taper connection implants represents a successful procedure for the rehabilitation of partially and completely edentulous arches. Mangano et $\mathrm{a}^{41}$ evaluated 1920 Morse tapered connection implants clinically and radiographically at 12, 24, 36 and 48 months after implant insertion. They noted an overall cumulative implant survival rate of $97.56 \%$ (96.12\% in maxilla and $98.91 \%$ in the mandible). The absence of an implant-abutment interface (microgap) is associated with minimal crestal bone loss.

\section{CONCLUSION}

Having reviewed the available literature, we have reached the conclusion that platform switching is capable of reducing or eliminating crestal bone loss to a mean of $1.56 \pm 0.7$ $\mathrm{mm}$. It also contributes to maintaining the width and height of crestal bone and the crestal peak between adjacent implants and it also limits the circumferential bone loss. We conclude that the implant design modifications involved in platform switching offer multiple advantages and potential applications, which include situations where a larger implant is desirable but the prosthetic space is limited and in the anterior zone where preservation of the crestal bone can lead to improved esthetics.

\section{REFERENCES}

1. Canullo L, Fedele GR, Iannello G, Jepren S. Platform switching and marginal bone-level alterations: the results of a randomizedcontrolled trial. Clin Oral Implants Res 2010;21(1):115-121.

2. Baumgarten $\mathrm{H}$, Cocchetto R, Testori T, Meltzer A, Porter S. A new implant design for crestal bone preservation: initial observations and case report. Pract Proceed Aesthet Dent 2005;17(10):735740 .

3. Lazzara RJ, Porter SS. Platform switching: a new concept in implant dentistry for controlling postoperative crestal bone levels. Int J Perio Rest Dent 2006;26(1):9-17.

4. Ericsson I, Persson LG, Berglundh T, Marinello CP, Lindhe J, Klinge B, et al. Different types of inflammatory reactions in peri-implant soft tissues. J Clin Perio 1995;22(3):255-261.

5. Atieh MA, Ibrahim HM, Atieh AH, et al. Platform switching for marginal bone preservation around dental implants: a systematic review and meta-analysis. J Perio 2010;81(10):1350-1366.

6. Deshpande SS, Sarin SP, Parkhedkar RD. Platform switching of dental implants: panacea for crestal bone loss. J Clin Diag Res 2009 Feb 3:1348-1352.

7. Luongo R, Traini T, Guidone PC, Bianco G, Cocchetto R, Celletti R. Hard and soft tissue responses to the platform-switching technique. Int J Periodont Restorat Dent 2008;28(6):551.

8. Maeda Y, Horisaka M, Yagi K. Biomechanical rationale for a single implant-retained mandibular overdenture: an in vivo study. Clin Oral Implants Res 2008;19(3):271-275.

9. Schrotenboer J, Tsao YP, Kinariwala V, Wang HL. Effect of platform switching on implant crest bone stress: a finite element analysis. Implant Dent 2009;18(3):260-269.
10. Canay, Senay, Akna. Biomechanical aspects of bone-level diameter shifting at implant abutment interface. Implant Dent 2009;18(3):239-248.

11. Hsu JT, Fuh LJ, Lin DJ, Shen YW, Huang HL. Bone strain and interfacial sliding analyses of platform switching and implant diameter on an immediately loaded implant: Experimental and three-dimensional finite element analyses. J Periodontol 2009;80(7):1125-1132.

12. Degidi M, Iezzi G, Scarano A, Piattelli A. Immediately loaded titanium implant with a tissue-stabilizing/maintaining design ('beyond platform switch') retrieved from man after 4 weeks: a histological and histomorphometrical evaluation: a case report. Clin Oral Implants Res 2008;19(3):276-282.

13. Miyata T, Kobayashi Y, Araki H, Ohto T, Shin K. The influence of controlled occlusal overload on peri-implant tissue. Part 3: a histologic study in monkeys. Int J Oral Maxillofac Implants 2000; 15:425-431.

14. Prosper L, Redaelli S, Pasi M, Zarone F, Radaelli G, GherloneEF. A randomized prospective multicenter trial evaluating the platformswitching technique for the prevention of postrestorative crestal bone loss. Int J Oral Maxillofac Implants 2009;24(2):299-308.

15. Prasad KD, Shetty M, Bansal N, Hegde C. Platform switchingan answer to crestal bone loss. J Dent Implant 2011;1(1):13-17.

16. Baggi L, Cappelloni I, Di Girolamo M, Maceri F, Vairo G. The influence of implant diameter and length on stress distribution of osseointegrated implants related to crestal bone geometry: a three-dimensional finite element analysis. J Prosthet Dent 2008;100(6):422-431.

17. Tabata LF, Assunção WG, Adelino Ricardo Barão V, de Sousa EA, Gomes EA, Delben JA. Implant platform switching: biomechanical approach using two-dimensional finite element analysis. J Craniofac Surg 2010;21(1):182-187.

18. Rodríguez-Ciurana X, Vela-Nebot X, Segalà-Torres M, RodadoAlonso C, Mendez-Blanco V, Mata-Bugueroles M. Biomechanical repercussions of bone resorption related to biologic width: a finite element analysis of three implant-abutment configurations. Int J Periodont Restorat Dent 2009;29(5):479-487.

19. Sabet ME, El-Korashy DI, El-Mahrouky NA. Effect of platform switching on strain developed around implants supporting mandibular overdenture. Implant Dent 2009;18(4):362-370.

20. Hermann F, Lerner H, Palti A. Factors influencing the preservation of the peri-implant marginal bone. Implant Dent 2007;16(2):165-175.

21. Wagenberg B, Froum SJ. Prospective study of 94 platformswitched implants observed from 1992 to 2006. Int J Periodont Restorative Dent 2010;30(1):9-17.

22. Becker J, Ferrari D, Herten M, Kirsch A, Schaer A, Schwarz F. Influence of platform switching on crestal bone changes at nonsubmerged titanium implants: a histomorphometrical study in dogs. J Clin Periodont 2007;34(12):1089-1096.

23. Spray JR, Black CG, Morris HF, Ochi S. The influence of bone thickness on facial marginal bone response: stage 1 placement through stage 2 uncovering. Ann Periodont 2000;5(1):119-128.

24. Cappiello M, Luongo R, Di Iorio D, Bugea C, Cocchetto R, Celletti R. Evaluation of peri-implant bone loss around platform-switched implants. Int J Periodont Restorative Dent 2008; 28(4):347-355.

25. López-Marí L, Calvo-Guirado JL, Martín-Castellote B, GomezMoreno G, López-Marí M. Implant platform switching concept: an updated review. Med Oral Patol Oral Cir Bucal 2009;14(9): e450-454. 
26. Becker J, Ferrari D, Mihatovic I, Sahm N, Schaer A, Schwarz F. Stability of crestal bone level at platform-switched nonsubmerged titanium implants: a histomorphometrical study in dogs. J Clin Periodont 2009;36(6):532-539.

27. Romanos GE, Nentwig GH. Immediate functional loading in the maxilla using implants with platform switching: five-year results. Int J Oral Maxillofac Implants 2009;24(6):1106-1112.

28. Prosper L, Crespi R, Valenti E, Capparé P, Gherlone E. Fiveyear follow-up of wide-diameter implants placed in fresh molar extraction sockets in the mandible: immediate versus delayed loading. Int J Oral Maxillofac Implants 2010;25(3):607-612.

29. Bilhan H, Mumcu E, Erol S, Kutay O. Influence of platformswitching on marginal bone levels for implants with mandibular overdentures: a retrospective clinical study. Implant Dent 2010; 19(3):250-258.

30. Romanos GE, Nentwig GH. Immediate loading using cross-arch fixed restorations in heavy smokers: nine consecutive case reports for edentulous arches. Int J Oral Maxillofac Implants 2008; 23(3):513-519.

31. Canullo L, Iurlaro G, Iannello G. Double-blind randomized controlled trial study on post-extraction immediately restored implants using the switching platform concept: soft tissue response. Preliminary report. Clin Oral Implants Res 2009;20(4): 414-420.

32. Cocchetto R, Traini T, Caddeo F, Celletti R. Evaluation of hard tissue response around wider platform-switched implants. Int $\mathrm{J}$ Periodont Restorat Dent 2010;30(2):163-171.

33. Calvo Guirado JL, Ortiz Ruiz AJ, Gómez Moreno G, López Marí L, Bravo González LA. Immediate loading and immediate restoration in 105 expanded-platform implants via the Diem System after a 16-month follow-up period. Med Oral Pathol Oral Cir Bucal 2008;13(9):E576-581.
34. Vela-Nebot X, Rodríguez-Ciurana X, Rodado-Alonso C, SegalàTorres M. Benefits of an implant platform modification technique to reduce crestal bone resorption. Implant Dent 2006;15(3):313-320.

35. Sorni-Bröker $M$, Peñarrocha-Diago $M$, Peñarrocha-Diago $M$. Factors that influence the position of the peri-implant soft tissues: a review. Med Oral Pathol Oral Cir Bucal 2009;14(9):e475-479.

36. Tarnow DP, Cho SC, Wallace SS. The effect of inter-implant distance on the height of inter-implant bone crest. J Periodont 2000;71(4):546-549.

37. Rodríguez-Ciurana X, Vela-Nebot X, Segalà-Torres M, CalvoGuirado JL, Cambra J, Méndez-Blanco V, Tarnow DP. The effect of interimplant distance on the height of the interimplant bone crest when using platform-switched implants. Int J Periodont Restorat Dent 2009;29(2):141-151.

38. Hürzeler M, Fickl S, Zuhr O, Wachtel HC. Peri-implant bone level around implants with platform-switched abutments: preliminary data from a prospective study. J Oral Maxillofac Surg 2007 Jul;65(7 Suppl 1):33-39. Erratum in: J Oral Maxillofac Surg 2008;66(10):2195-2196.

39. Canullo L, Rasperini G. Preservation of peri-implant soft and hard tissues using platform switching of implants placed in immediate extraction sockets: a proof-of-concept study with 12- to 36-month follow-up. Int J Oral Maxillofac Implants 2007;22(6):995-1000.

40. Trammell K, Geurs NC, O’Neal SJ, Liu PR, Haigh SJ, McNeal S, Kenealy JN, Reddy MS. A prospective, randomized, controlled comparison of platform-switched and matched-abutment implants in short-span partial denture situations. Int J Periodont Restorat Dent 2009;29(6):599-605.

41. Mangano C, Mangano F, Piattelli A, Iezzi G, Mangano A, La Colla L. Prospective clinical evaluation of 1920 Morse taper connection implants: results after 4 years of functional loading. Clin Oral Impl Res 2009;20(3):254-261. 